\title{
Deteksi Keberadaan Escherichia coli dan Staphylococcus aureus pada Pangan Tradisional Babi Panggang Karo (BPK) di Kecamatan Kuta Selatan, Kuta dan Denpasar Timur
}

\section{Detection of the Existence of Escherichia coli and Staphylococcus aureus in Traditional Food of Karo Roasted Pork (BPK) in subdistricts of South Kuta, Kuta and East Denpasar}

\author{
Lusia Septryani Sidebang ${ }^{1}$, Luh Putu Trisna Darmayanti ${ }^{1 *}$, I Ketut Suter ${ }^{1}$ \\ Program Studi Teknologi Pangan, Fakultas Teknologi Pertanian, Universitas Udayana \\ Kampus Bukit Jimbaran, Badung-Bali \\ *Penulis korespondensi: Luh Putu Trisna Darmayanti, Email: darmayantitrisna@unud.ac.id
}

\begin{abstract}
Karo roasted pork is a traditional Batak food made from roasted pork and served with a sauce made from pork blood cooked with andaliman herbs and spices. This study aims to detect the presence of microbes and the food safety of karo roasted pork sold in Batak restaurants in subdistricts of South Kuta, Kuta and East Denpasar. This study used a survey method with a saturated sampling technique. The samples were determined in all restaurants selling karo roasted pork in Badung Regency, Bali. The research data were presented in tabular form and analyzed descriptively. The variables observed were total microbes, Escherichia coli and Staphylococcus aureus. The results showed that $71 \%$ of the restaurants meet the total microbial requirements of processed meat products with heat treatment based on SNI 7388:2009 are $<5 \mathrm{x}$ $10^{5} .57 \%$ of karo roast pork has not met the requirements for E.coli contamination limits in processed meat in Indonesia, and $100 \%$ of karo roasted pork has met the S.aureus requirements for processed meat in Indonesia. As many as $57 \%$ of producers process karo roast pork if there is an order. Sanitation and hygiene practices at Batak traditional restaurants in Badung regency, Bali are quite good.
\end{abstract}

Keywords: karo roasted pork, microbial detection, food safety

\section{PENDAHULUAN}

Makanan Tradisional merupakan suatu wujud budaya yang mempunyai ciri kedaerahan, spesifik, dan beraneka ragam yang mencerminkan potensi alam daerah masing-masing. Selain sebagai sarana untuk memenuhi kebutuhan gizi, makanan juga berguna untuk mempertahankan hubungan antar manusia, simbol identitas masyarakat, dan dapat dipromosikan untuk menunjang pariwisata yang dapat mendukung pendapatan suatu daerah (Endang et al, 2013). Babi panggang karo atau yang lebih populer dikenal dengan istilah BPK merupakan makanan tradisional yang berasal dari Provinsi Sumatera Utara, terbuat dari daging babi yang dipanggang dengan menggunakan rempah khas suku Batak yaitu andaliman. Babi panggang karo banyak digemari oleh penduduk setempat maupun secara nasional melalui lapo atau rumah makan khas Batak yang tersebar di kota-kota besar, Indonesia dan salah satunya adalah Bali (Anon, 2019).

Dalam pembuatan babi panggang karo menggunakan daging babi yang agak berlemak, daging babi tersebut dicampur dengan bumbu dan perasan jeruk nipis, kemudian dipanggang menggunakan arang. Babi panggang tersebut disajikan dengan saus gota atau darah babi yang dimasak dengan rempah khas Batak yaitu Andaliman. Babi panggang karo memiliki aroma dan rasa yang khas yang dihasilkan oleh andaliman. Sedangkan be guling merupakan makanan khas yang terbuat dari anak babi betina 
atau jantan dimana pada bagian perutnya dikeluarkan lalu diisi bumbu base genep dan sayuran seperti daun singkong, lalu dipanggang dengan cara diputar-putar (diguling-guling) sampai matang ditandai dengan warna kulit yang berubah menjadi kecoklatan dan renyah. Makanan tradisional babi panggang karo pada awalnya hanya dikonsumsi jika ada acara besar seperti perayaan musim panen besar, acara tahunan desa dan acara keluarga, karena babi panggang karo identik dengan lambang kemakmuran dan kesuburan. Tetapi, seiring perkembangan zaman dan pertambahan jumlah penduduk, babi panggang karo mulai menjadi konsumsi masyarakat dan mulai dijual di lapo atau rumah makan khas Batak yang sudah banyak tersebar di seluruh Indonesia.

Makanan tradisional pada umumnya memiliki beberapa kelemahan dalam hal keamanannya terhadap bahaya mikrobiologi, kimia dan fisik. Adanya cemaran seringkali ditemukan karena rendahnya mutu bahan baku, teknologi pengolahan, belum diterapkannya praktik sanitasi dan higiene yang memadai dan kurangnya kesadaran pekerja maupun produsen dalam penanganan makanan tradisional tersebut (Nanuwasa, 2007). Olahan makanan tradisional seperti babi panggang karo yang menggunakan daging babi sebagai bahan utama perlu diperhatikan proses penanganan hingga pengolahannya. Mikroba patogen yang sering mengkontaminasi daging babi olahan adalah Escherichia coli dan Staphylococcus aureus yang menyebabkan penurunan kualitas, menimbulkan masalah serta memiliki dampak yang cukup berbahaya bagi kesehatan (Supar, 2005).
Keberadaan bakteri E.coli dalam daging mentah atau daging dengan proses pematangan yang kurang sempurna dan tercemar oleh kotoran manusia ataupun hewan dapat menyebabkan penyakit, sehingga dalam mikrobiogi pangan E.coli disebut sebagai bakteri indikator sanitasi (Supardi dan Sukanto, 1999). Sedangkan keberadaan bakteri S.aureus dalam makanan sebagai bakteri patogen penyebab food poisoning yang dapat menimbulkan terjadinya gastroenteritis akibat mengkonsumsi makanan yang mengandung satu atau lebih enterotoksin yang dihasilkannya.

Keamanan pangan merupakan kondisi dan upaya yang perlu dilakukan untuk mencegah pangan dari kemungkinan cemaran biologis, kimia dan benda lain yang dapat mengganggu, merugikan, dan membahayakan kesehatan manusia. Dengan demikian dapat didefinisikan bahwa pangan yang aman adalah pangan yang tidak mengandung bahaya mikrobiologi, bahaya kimia dan bahaya fisik. Sumber kontaminan yang mencemari bahan pangan dapat berasal dari bahan mentah hingga siap untuk dikonsumsi (Saparinto, 2006). Keamanan pangan dapat dicapai melalui kebijakan, peraturan, standar, penelitian, pengawasan dan pemeriksaan dan upaya lainnya yang diterapkan untuk mengurangi resiko atau pengendalian bahaya dalam rantai pasokan pangan (Knechtges, 2015).

Penelitian ini bertujuan untuk mendeteksi keberadaan mikroba E.coli dan S.aureus pada babi panggang karo yang dijual di rumah makan khas Batak di Kecamatan Kuta Selatan, Kuta dan Denpasar Timur dan mengetahui apakah babi panggang karo masih memenuhi syarat untuk 
dikonsumsi. Hasil yang diperoleh diharapkan dapat dipakai sebagai acuan untuk menentukan aman atau tidaknya babi panggang karo untuk dikonsumsi.

\section{METODE PENELITIAN}

\section{Tempat dan Waktu}

Penelitian ini dilaksanakan pada rumah makan khas Batak yang menjual babi panggang karo di Kecamatan Kuta Selatan, Kuta dan Denpasar Timur yaitu BPK Jimbaran, BPK Legian, BPK Kuta, BPK Benoa, BPK Pulau Moyo, BPK Pemogan, BPK Denpasar dan Laboratorium Mikrobiologi Pangan Fakultas Teknologi Pertanian, Universitas Udayana. Waktu pelaksanaan pada September - November 2020.

\section{Alat dan Bahan}

Alat yang digunakan dalam pengujian ini adalah cold box (Marina cooler), plastik PE, aluminium foil, cawan petri (Anumbra), tabung reaksi (Iwaki), pipet volumetric (Iwaki), botol media, pipet mikro (Akura), gelas ukur (Pyrex), Erlenmeyer $1000 \mathrm{ml}$ (Pyrex), blue tip, gunting, pinset, rak tabung, vortex (Gemmy), bunsen, timbangan analitik (Ohaus), medical sterilizer (Fortune), inkubator (Memert), autoklaf (Hirayama), stomatcher (Interscience), spreader, laminar air flow (Kojai).

Bahan yang digunakan dalam pengujian ini ialah sampel babi panggang karo, pepton water, Plate Count Agar (PCA), Easin Methylene Blue Agar (EMBA), Baird Parker Agar (BPA), Aquades, alkohol 96\%.

\section{Pelaksanaan Penelitian}

Pelaksanaan penelitian terdiri dari beberapa tahapan yaitu:

\section{Pengumpulan data}

Pengumpulan data ini dilaksanakan dengan menyebarkan daftar pertanyaan atau kuisioner dan wawancara kepada seluruh produsen yang menjual babi panggang karo di Kecamatan Kuta Selatan, Kuta dan Denpasar Timur. Data hasil penelitian disajikan dalam bentuk tabel, gambar dan di analisis secara deskriptif (Gomez dan Gomez, 1995).

\section{Pengambilan sampel}

Teknik pengambilan sampel yang digunakan ialah sampling jenuh yaitu teknik penentuan sampel bila semua anggota populasi digunakan sebagai sampel. Teknik ini dilakukan apabila jumlah populasi relatif kecil, kurang dari 30. Sampel jenuh disebut juga dengan istilah sensus, dimana semua anggota populasi dijadikan sampel (Sugiyono, 2001).

\section{Prosedur pengambilan sampel}

Pengambilan sampel dilakukan pada pukul 10.00 WITA di rumah makan khas Batak yang menjual babi panggang karo di Kecamatan Kuta Selatan, Kuta dan Denpasar Timur. Diambil 1 porsi sampel dari masing-masing rumah makan. Pada saat pengambilan sampel, alat yang digunakan berupa wadah plastik dan cold box yang sudah disterilkan dengan alkohol. Sampel dimasukkan kedalam plastik PE kemudian disimpan dalam cold box selama diperjalanan.

\section{Preparasi sampel}

Preparasi sampel berdasarkan metode pengujian total mikroba, Escherichia coli, dan 
Staphylococcus aureus pada produk olahan daging dalam SNI 2897:2008. Ditimbang sampel babi panggang karo sebanyak $5 \mathrm{~g}$, dimasukkan kedalam botol steril yang berisi $45 \mathrm{ml} \mathrm{PW} \mathrm{(Pepton} \mathrm{Water),}$ kemudian dihomogenkan dengan vortex dan hasil homogenan adalah pengenceran $10^{-1}$. Disiapkan pengenceran $10^{-2}, 10^{-3}, 10^{-4}$ yang berisi $9 \mathrm{ml} \mathrm{PW}$. Diambil dengan pipet $1 \mathrm{ml}$ larutan homogenan dari tabung $10^{-1}$ lalu dipindahkan ke tabung PW $10^{-2}, 1$ $\mathrm{ml} \mathrm{PW} 10^{-2}$ dipindahkan ke tabung PW $10^{-3}$, dan 1 ml PW $10^{-3}$ dipindahkan ketabung PW $10^{-4}$.

\section{Variabel yang Diamati}

Variabel yang diamati pada penelitian ini adalah total mikroba, Escherichia coli dan Staphylococcus aureus dianalisis dengan metode pengujian cemaran mikroba dalam olahan daging (Anon, 2008).

\section{Analisis Total Mikroba}

Analisis total mikroba pada sampel babi panggang karo menggunakan metode Total Plate Count (TPC) dimana koloni yang tumbuh dihitung dan dilaporkan sebagai jumlah koloni per gram. Dituang $20 \mathrm{ml}$ media Plate Count Agar (PCA) yang sudah didinginkan hingga $45^{\circ} \mathrm{C}$ pada masingmasing cawan. Diinokulasi $1 \mathrm{ml}$ suspensi dari tabung $10^{-2}$ sampai $10^{-4}$ ditengah-tengah cawan petri yang dilakukan secara duplo. Diratakan permukaan menggunakan spreader agar tidak terbentuk gelembung udara. Diinkubasi pada suhu $35^{\circ} \mathrm{C}$ selama 24 - 48 jam dengan meletakkan cawan dengan posisi terbalik. Dihitung koloni pada setiap seri pengenceran dengan cara rerata jumlah koloni percawan dan dikalikan dengan faktor pengencerannya.

\section{Analisis Escherichia coli}

Analisis Escherichia coli menggunakan metode sebar dengan media Eosin Methylene Blue Agar (EMBA). Diinokulasi $1 \mathrm{ml}$ suspensi dari tabung $10^{-2}$ sampai $10^{-4}$ ditengah-tengah cawan petri yang dilakukan secara duplo. Diratakan permukaan menggunakan spreader dan diinkubasi pada suhu $35^{\circ} \mathrm{C}$ selama $24-48$ jam dengan meletakkan cawan dengan posisi terbalik. Setelah 24 jam penampakan E.coli dengan terbentuknya koloni tipikal yang berwarna hitam dibagian tengahnya dengan atau tanpa bayangan hijau metalik (Fardiaz, 1992).

\section{Analisis Staphylococcus aureus}

Analisis Staphylococcus aureus menggunakan metode sebar dengan media Baird Parker Agar (BPA). Diinokulasi $1 \mathrm{ml}$ suspensi dari tabung $10^{-2}$ sampai $10^{-4}$ ditengah-tengah cawan petri yang dilakukan secara duplo. Diratakan permukaan menggunakan spreader dan diinkubasi pada suhu $35^{\circ} \mathrm{C}$ selama 24 - 48 jam dengan meletakkan cawan dengan posisi terbalik. Bakteri S.aureus memiliki ciri koloni berwarna hitam mengkilat dan dikelilingi oleh areal bening.

\section{HASIL DAN PEMBAHASAN}

\section{Karakteristik Rumah Makan BPK di Kecamatan Kuta Selatan, Kuta dan Denpasar Timur}

Penelitian ini dilaksanakan dengan melakukan wawancara dengan karyawan yang bekerja di rumah makan yang menjual babi panggang karo di Kecamatan Kuta Selatan, Kuta dan Denpasar Timur. Adapun jumlah populasi rumah makan yang menjual babi panggang karo di Kecamatan Kuta Selatan, Kuta dan Denpasar 
Timur yang diambil sebagai sampel penelitian adalah sebanyak 7 rumah makan. Berdasarkan hasil survei yang didapatkan dari daftar pertanyaan tentang keamanan pangan yang meliputi kondisi bahan baku, kondisi proses pengolahan dan penyimpanan, personal higiene dan praktek sanitasi rumah makan yang menjual babi panggang karo di Kecamatan Kuta Selatan, Kuta dan Denpasar Timur maka didapatkan hasil sebagai berikut:

\section{Kondisi bahan baku babi panggang karo}

Berdasarkan hasil survei penelitian menunjukkan bahwa sebanyak $100 \%$ produsen di rumah makan khas Batak di Kecamatan Kuta Selatan, Kuta dan Denpasar Timur mendapatkan bahan baku daging babi dari pasar yang berada di sekitar Kecamatan
Kuta Selatan, Kuta dan Denpasar Timur seperti pasar senggol. Pasar tradisional merupakan salah tempat pemasaran daging yang sanitasi lingkungannya kurang baik sehingga rawan dan beresiko tinggi terhadap cemaran mikroba patogen (Irianto, 2006). Pasar tradisional memiliki kemungkinan kontaminasi dan tempat perkembangbiakan mikroba yang tinggi karena kurangnya kesadaran pedagang mengenai kesehatan daging yang dapat mengakibatkan daging terkontaminasi mikroba patogen dan dapat berakibat buruk terhadap kesehatan manusia. Hasil survei terhadap kondisi bahan baku dalam pembuatan babi panggang karo dapat dilihat pada Tabel 1

Tabel 1. Hasil survei terhadap tempat pembelian dan metode penyimpanan bahan baku pada babi panggang karo yang dijual pada rumah makan khas Batak di Kecamatan Kuta Selatan, Kuta dan Denpasar Timur.

\begin{tabular}{|c|c|c|c|}
\hline No. & Variabel yang diamati & Jumlah & Persentase \\
\hline 1 & $\begin{array}{l}\text { Tempat pembelian bahan baku } \\
\text { - Pasar }\end{array}$ & 7 & $100 \%$ \\
\hline 2 & $\begin{array}{l}\text { Jenis bahan baku } \\
\text { - Lokal }\end{array}$ & 7 & $100 \%$ \\
\hline 3 & $\begin{array}{l}\text { Bahan baku langsung diolah } \\
\text { - } \quad \text { Ya } \\
\text { - Tidak }\end{array}$ & $\begin{array}{l}3 \\
4\end{array}$ & $\begin{array}{l}43 \% \\
57 \%\end{array}$ \\
\hline 4 & $\begin{array}{l}\text { Penyimpanan bahan baku } \\
\text { - } \quad \text { Freezer } \\
\text { - } \quad \text { Lemari pendingin } \backslash\end{array}$ & $\begin{array}{l}4 \\
3\end{array}$ & $\begin{array}{l}57 \% \\
43 \%\end{array}$ \\
\hline 5 & $\begin{array}{l}\text { Maksimal lama penyimpanan } \\
-\quad 1 \text { hari } \\
-\quad>1 \text { hari }\end{array}$ & $\begin{array}{l}2 \\
5\end{array}$ & $\begin{array}{l}29 \% \\
71 \% \\
\end{array}$ \\
\hline
\end{tabular}

Menurut Soeparno (2009), kontaminasi mikroba pada daging dimulai sejak berhentinya peredaran darah pada saat penyembelihan, terutama apabila alat yang digunakan pada saat penyembelihan tidak steril. Kontaminasi selanjutnya dapat terjadi melalui permukaan daging selama proses persiapan, pemotongan karkas atau daging, penyimpanan dan proses distribusi. Segala sesuatu kontak langsung atau tidak langsung dengan daging bisa merupakan 
sumber kontaminasi mikroba. Jenis daging babi yang digunakan sebagai bahan baku babi panggang karo ialah daging babi lokal. Sebanyak 57\% daging babi yang diperoleh dari pasar tidak langsung diolah oleh produsen melainkan dicuci terlebih dahulu kemudian disimpan dalam wadah tertutup dan dimasukkan ke dalam freezer. Daging babi tersebut diolah pada pagi hari atau diolah di hari selanjutnya. Sebanyak $71 \%$ produsen menyimpan daging babi lebih dari 1 hari.

\section{Kondisi proses pengolahan dan penyimpanan}

Babi panggang karo diolah dengan cara daging babi diiris tipis diberi perasan air jeruk nipis, ditambah bumbu yang sudah dihaluskan yaitu batang serai dan bawang putih serta kecap manis dan garam, lalu didiamkan beberapa saat hingga bumbu meresap kedalam daging lalu dipanggang menggunakan arang. Babi panggang tersebut disajikan dengan saus gota yang merupakan darah babi yang dimasak dengan bumbu seperti bawah merah, bawang putih, cabai, andaliman yang telah dihaluskan, daun jeruk purut, ditambahkan air hasil perasan asam patikala, lalu ditambahkan sedikit garam dan penyedap masakan, dimasak menggunakan api kecil hingga matang. Babi panggang karo memiliki aroma dan rasa yang khas yang dihasilkan oleh rempah Andaliman. Hasil survei terhadap kondisi proses pengolahan dan penyimpanan babi panggang karo dapat dilihat pada Tabel 2.

Tabel 2. Hasil survei kondisi terhadap proses pengolahan babi panggang karo dan penyimpanan babi panggang karo di rumah makan khas Batak di Kecamatan Kuta Selatan, Kuta dan Denpasar Timur.

\begin{tabular}{|c|c|c|c|}
\hline No. & Variabel yang diamati & Jumlah & Persentase \\
\hline \multirow[t]{3}{*}{1} & Waktu pembuatan babi panggang karo & & \\
\hline & - Pagi & 3 & $43 \%$ \\
\hline & - Saat ada pesanan & 4 & $57 \%$ \\
\hline \multirow[t]{3}{*}{2} & $\begin{array}{l}\text { Maksimal lama penyajian pada lemari } \\
\text { kaca }\end{array}$ & & \\
\hline & $-\quad 4$ jam & 4 & $57 \%$ \\
\hline & $-\quad<4$ jam & 3 & $43 \%$ \\
\hline \multirow[t]{2}{*}{3} & $\begin{array}{l}\text { Maksimal lama penyimpanan babi } \\
\text { panggang karo }\end{array}$ & & \\
\hline & - Tidak disimpan & 7 & $100 \%$ \\
\hline
\end{tabular}

Hasil data survei penelitian produsen di rumah makan khas Batak Kecamatan Kuta Selatan, Kuta dan Denpasar Timur pada Tabel 2 menunjukkan bahwa sebanyak 57\% rumah makan khas Batak menyimpan daging babi yang sudah ditambahkan bumbu di lemari pendingin dan hanya melakukan pemanggangan jika ada pesanan dari pembeli. Hal ini dapat memicu pertumbuhan mikroba karena lamanya waktu proses pengolahan. Daging babi yang sudah ditambahkan bumbu sebaiknya langsung dipanggang karena jika daging mengalami perubahan dari suhu ruang ke suhu 
dingin secara berulang dapat menyebabkan terjadinya kontaminasi dan mempercepat pertumbuhan bakteri. Sesuai dengan pengujian pada $\mathrm{R}_{1}, \mathrm{R}_{2}, \mathrm{R}_{5}$ dan $\mathrm{R}_{7}$ terbukti tercemar oleh bakteri E.coli sehingga tidak memenuhi syarat karena telah melewati batas maksimum cemaran mikroba olahan daging. Dalam proses penyimpanan dilemari kaca, sebanyak 57\% rumah makan khas Batak menyajikan babi panggang karo selama 4 jam sesuai dengan penjualan. Babi panggang karo diletakkan dalam wadah tertutup sehingga dapat mengurangi terjadinya kontaminasi silang dengan udara. $100 \%$ babi panggang karo yang dijual di rumah makan khas Batak tidak ada proses penyimpanan.

\section{Personal higiene}

Hasil survei terhadap personal higiene karyawan pada rumah makan khas Batak dapat dilihat pada Tabel 3.

Tabel 3. Hasil survei terhadap personal higiene karyawan di rumah makan khas Batak di Kecamatan Kuta Selatan, Kuta dan Denpasar Timur.

\begin{tabular}{clcc}
\hline No. & \multicolumn{1}{c}{ Variabel yang diamati } & Jumlah & Persentase \\
\hline 1 & $\begin{array}{l}\text { Cara pengambilan sampel } \\
-\quad \text { Capit }\end{array}$ & 7 & $100 \%$ \\
2 & $\begin{array}{l}\text { Kelengkapan karyawan (hairnet, masker } \\
\text { dan sarung tangan) }\end{array}$ & 7 & $100 \%$ \\
$\quad \begin{array}{l}\text { Frekuensi mencuci tangan } \\
3\end{array}$ & 5 & $71 \%$ \\
& $-\quad$ Sebelum dan sesudah beraktivitas & 2 & $29 \%$ \\
4 & $-\quad$ Seperlunya & 2 & $29 \%$ \\
& $\begin{array}{l}\text { Menggunakan aksesoris di tangan } \\
\text { - Ya }\end{array}$ & 5 & $71 \%$ \\
\hline
\end{tabular}

Berdasarkan hasil survei penelitian terhadap praktek personal higiene di rumah makan khas Batak di Kecamatan Kuta Selatan, Kuta dan Denpasar Timur menunjukkan bahwa karyawan memiliki kondisi kesehatan yang baik, tidak sedang mengalami batuk, pilek, tidak memiliki luka pada kulit, menggunakan pakaian kerja yang bersih dan rapi. Rata-rata jumlah karyawan yang bekerja di rumah makan khas Batak di Kecamatan Kuta Selatan, Kuta dan Denpasar Timur berjumlah 2-3 orang. Sebanyak 100\% karyawan menyajikan babi panggang karo menggunakan capit, dimana penggunaan capit dinilai lebih baik dari pada menggunakan tangan secara langsung dapat menyebabkan kontaminasi silang antara tangan dengan babi panggang karo. Sebanyak 100\% karyawan tidak menggunakan kelengkapan karyawan selama proses pengolahan. Sebanyak $71 \%$ karyawan telah menerapkan prinsip mencuci tangan dengan sabun sebelum dan sesudah melakukan pengolahan dan penyajian babi panggang karo. Frekuensi mencuci tangan yang dilakukan oleh pekerja sebelum dan sesudah melakukan aktivitas juga dapat menurunkan kontaminasi silang terhadap produk yang dihasilkan. Sebanyak 79\% karyawan tidak menggunakan aksesoris selama proses pengolahan. 
Personal higiene sangat penting karena bagian-bagian tubuh seperti tangan, hidung, dan mulut merupakan jalan masuk mikroba dalam mencemari makanan selama proses penyiapan, pengolahan dan penyajian melalui sentuhan dan pernapasan. Praktek personal higiene untuk menjaga kebersihan diri sendiri merupakan salah satu upaya untuk mencegah terjadinya kontaminasi silang atau penularan penyakit. Jika dalam pengolahan pangan personal higiene belum diterapkan dengan baik hal tersebut akan berpengaruh terhadap hasil akhir dengan nilai keamanan pangan yang rendah (Sandjaja, 2009).

\section{Praktek sanitasi pada rumah makan yang menjual babi panggang karo di Kecamatan Kuta Selatan, Kuta dan Denpasar Timur}

Berdasarkan hasil survei yang telah dilakukan menunjukkan bahwa 100\% lemari kaca dibersihkan di pagi hari ketika akan memulai berjualan dan setelah berjualan. Untuk peralatan hanya dibersihkan ketika sudah selesai berjualan saja, pada saat proses pengolahan dan penyajian seringkali alat digunakan berulang-ulang sehingga memungkinkan terjadinya kontaminasi E.coli pada produk. Keberadaan E.coli dalam makanan juga dipengaruhi oleh rendahnya praktek sanitasi (Pratidina et al., 2007). Membersihkan lingkungan rumah makan juga dilakukan pada pagi hari yang mencakup menyapu, mengepel dan membuang limbah sampah. Hasil survei terhadap praktek sanitasi di rumah makan khas Batak dapat dilihat pada Tabel 4.

\section{Total Mikroba}

Hasil pengujian total mikroba pada babi panggang karo yang dijual rumah makan khas Batak di Kecamatan Kuta Selatan, Kuta dan Denpasar Timur dapat dilihat pada Tabel 5.

Tabel 4. Hasil survei terhadap praktek sanitasi di rumah makan khas Batak di Kecamatan Kuta Selatan, Kuta dan Denpasar Timur.

\begin{tabular}{clcc}
\hline No. & \multicolumn{1}{c}{ Variabel yang diamati } & Jumlah & Persentase \\
\hline 1 & $\begin{array}{l}\text { Membersihkan lemari kaca } \\
-\quad \text { Ya }\end{array}$ & 7 & $100 \%$ \\
2 & $\begin{array}{l}\text { Membersihkan peralatan pengolahan babi } \\
\text { panggang karo }\end{array}$ & 7 & $100 \%$ \\
$\quad \begin{array}{l}\text { Pembersihan dan sanitasi ruang sebelum } \\
\text { dan sesudah aktivitas }\end{array}$ & & $100 \%$ \\
\hline$\quad$ Ya & 7 & \\
\hline
\end{tabular}

Tabel 5 menunjukkan bahwa total mikroba pada 7 sampel babi panggang karo di rumah makan khas Batak Kecamatan Kuta Selatan, Kuta dan Denpasar Timur terdapat $71 \%$ rumah makan yang masih memenuhi syarat batasan maksimum cemaran mikroba pada produk olahan daging dengan perlakuan panas. Total mikroba terendah ditemukan pada sampel $\mathrm{R}_{2}$ yaitu 3,2 x 104 koloni/g. Persyaratan batas maksimum cemaran mikroba pada produk olahan daging dengan perlakuan panas ialah $1 \times 10^{5} \mathrm{koloni} / \mathrm{g}$ sesuai dengan SNI 7388:2009 (Anon, 2009). Hal tersebut 
menunjukkan bahwa babi panggang karo yang dijual masih memenuhi syarat dan kualitas keamanan pangan. Benarnya proses selama pengolahan, penyajian serta menerapkan personal higiene dengan baik berpengaruh terhadap rendahnya nilai total mikroba yang dihasilkan.

Tabel 5. Total mikroba pada babi panggang karo di rumah makan khas Batak Kecamatan Kuta Selatan, Kuta dan Denpasar Timur.

\begin{tabular}{cccc}
\hline $\begin{array}{c}\text { Sampel Babi } \\
\text { Panggang Karo }\end{array}$ & $\begin{array}{c}\text { Total Mikroba } \\
\text { (koloni/g }\end{array}$ & $\begin{array}{c}\text { SNI 7388: 2009 olahan } \\
\text { daging }(\text { koloni/g) }\end{array}$ & Keterangan \\
\hline R1 & $5,7 \times 10^{4}$ & $1 \times 10^{5}$ & Memenuhi syarat \\
R2 & $3,2 \times 10^{4}$ & $1 \times 10^{5}$ & Memenuhi syarat \\
R3 & $1 \times 10^{5}$ & $1 \times 10^{5}$ & Memenuhi syarat \\
R4 & $6,7 \times 10^{4}$ & $1 \times 10^{5}$ & Memenuhi syarat \\
R5 & $7,1 \times 10^{4}$ & $1 \times 10^{5}$ & Memenuhi syarat \\
R6 & $3 \times 10^{5}$ & $1 \times 10^{5}$ & Tidak memenuhi syarat \\
R7 & $6 \times 10^{5}$ & $1 \times 10^{5}$ & Tidak memenuhi syarat \\
\hline
\end{tabular}

Tetapi dari hasil pengujian total mikroba pada Tabel 5 ditemukan sebanyak 2 (29\%) sampel babi panggang karo yang tidak memenuhi syarat atau melebihi standar SNI 7338:2009. Sampel $\mathrm{R}_{7}$ memiliki nilai total mikroba tertinggi yaitu $6 \times 10^{5}$ koloni/g, sehingga kualitas keamanan pangan sangat rendah dan tidak layak untuk dikonsumsi. Tingginya jumlah total mikroba dapat disebabkan oleh penanganan bahan baku yang kurang tepat, alat yang digunakan selama proses pengolahan kurang diperhatikan kebersihannya, dan daging yang akan dipanggang diletakkan di ruang terbuka yang akan memicu peningkatan pertumbuhan mikroba. Bahan pangan sebagian besar disusun oleh komponen utama seperti protein, karbohidrat, dan lemak merupakan sumber nutrisi dari pertumbuhan, perkembangan, dan penyebaran mikroba sehingga sangat memungkinkan kandungan mikroba pada bahan pangan sudah terdapat sejak bahan pangan tersebut berbentuk bahan dasar (Supardi et al, 1999). Kontaminasi dapat juga dapat dipengaruhi oleh air yang digunakan selama proses pengolahan, lingkungan, suhu, dan praktek sanitasi higiene yang diterapkan. Selain itu jumlah total mikroba juga dapat dipengaruhi pada saat proses pemotongan daging hingga proses pencuciannya.

\section{Uji Escherichia coli}

Hasil pengujian cemaran Escherichia coli pada babi panggang karo di rumah makan khas Batak Kecamatan Kuta Selatan, Kuta dan Denpasar Timur dapat dilihat pada Tabel 6.

Tabel 6 menunjukkan bahwa sebanyak $57 \%$ babi panggang karo positif tercemar bakteri E.coli yaitu sampel $\mathrm{R}_{1}, \mathrm{R}_{2}, \mathrm{R}_{5}$, dan $\mathrm{R}_{7}$. Cemaran E.coli tertinggi ditemukan pada sampel $\mathrm{R}_{2}$ yaitu 1,6 x $10^{5} \mathrm{koloni} / \mathrm{g}$ telah melebihi batasan maksimum cemaran E.coli, dimana persyaratan batasan maksimum cemaran E.coli pada produk olahan daging dengan perlakuan panas adalah $<3$ koloni $/ \mathrm{g}$ menurut SNI 7388:2009. Berdasarkan data hasil kuisioner sumber kontaminasi yang memungkinkan terjadinya cemaran berasal dari air yang terkontaminasi E.coli. Air tersebut digunakan 
untuk mencuci daging, mencuci alat-alat dan mencuci tangan tanpa menggunakan sabun. Selain itu penggunaan alat seperti capit, piring, pisau dan talenan digunakan berulang kali selama proses pengolahan. Menurut Laluraa et al (2014) penjamah makanan yang menggunakan peralatan yang tidak bersih dan digunakan secara berulang- ulang serta hanya disimpan di ruang terbuka dapat memacu terjadinya kontaminasi mikroba. Kotoran yang tertinggal pada peralatan berasal dari sisa makanan yang masih menempel dan debu dari polusi udara akibat penyimpanan peralatan pada ruang terbuka (Faridz, 2007).

Tabel 6. Uji Escherichia coli pada babi panggang karo di rumah makan khas Batak di Kecamatan Kuta Selatan, Kuta dan Denpasar Timur.

\begin{tabular}{cccc}
\hline $\begin{array}{c}\text { Sampel Babi } \\
\text { Panggang Karo }\end{array}$ & Escherichia coli (koloni/g & $\begin{array}{c}\text { SNI 7388: 2009 olahan } \\
\text { daging (koloni/g) }\end{array}$ & Keterangan \\
\hline R1 & $1,4 \times 10^{5}$ & 3 & Tidak memenuhi syarat \\
R2 & $1,6 \times 10^{5}$ & 3 & Tidak memenuhi syarat \\
R3 & Negatif & 3 & Memenuhi syarat \\
R4 & Negatif & 3 & Memenuhi syarat \\
R5 & $5,7 \times 10^{4}$ & 3 & Tidak memenuhi syarat \\
R6 & Negatif & 3 & Memenuhi syarat \\
R7 & $6,3 \times 10^{4}$ & 3 & Tidak memenuhi syarat \\
\hline
\end{tabular}

Proses pemanggangan yang kurang memperhatikan higiene juga dapat berpengaruh terhadap terjadinya kontaminasi silang. Menurut Soeparno (2009), adanya proses pengasapan dengan menggunakan asap yang kurang pekat dan para-para besi yang kotor, serta makanan yang sudah diolah berhubungan langsung dengan peralatan yang sebelumnya telah tercemar dapat memacu tingkat pertumbuhan bakteri dan mengandung bakteri yang cukup tinggi dan beragam jenisnya. Tingginya cemaran E.coli juga dapat disebabkan oleh saus gota atau darah babi yang dimasak. Pada saat pemotongan babi di rumah potong dapat terjadi kontaminasi pada darah, dimana darah tersebut hanya diletakkan pada wadah terbuka sehingga rentan terhadap cemaran dari lingkungan sekitar. Selain itu, proses pengolahan, produsen yang mengolah, proses pematangan yang kurang sempurna dan penyimpanan juga dapat berpengaruh terhadap mutu dari saus gota yang dihasilkan.

Tingginya tingkat cemaran E.coli pada suatu bahan pangan sangat berpengaruh terhadap keamanan pangan. Sampel yang terkontaminasi oleh bakteri E.coli dan melebihi batas cemaran, maka bahan pangan tersebut tidak layak konsumsi dan keamanan pangan rendah. Faktor yang menetukan keamanan makanan ialah jenis makanan olahan, cara penanganan dan penyajian, tempat dan suhu penyimpanan baik bahan mentah maupun sudah matang, serta waktu antara makanan matang hingga dikonsumsi (Tamaroh, 2002).

\section{Uji Staphylococcus aureus}

Hasil pengujian S.aureus pada babi panggang karo di rumah makan khas Batak Kecamatan Kuta Selatan, Kuta dan Denpasar Timur dapat dilihat pada Tabel 7. 
Tabel 7. Uji Staphylococcus aureus pada babi panggang karo di rumah makan khas Batak di Kecamatan Kuta Selatan, Kuta dan Denpasar Timur.

\begin{tabular}{cccc}
\hline $\begin{array}{c}\text { Sampel Babi } \\
\text { Panggang Karo }\end{array}$ & $\begin{array}{c}\text { Staphylococcus aureus } \\
\text { koloni/g }\end{array}$ & $\begin{array}{c}\text { SNI 7388: 2009 olahan } \\
\text { daging (koloni/g) }\end{array}$ & Keterangan \\
\hline R1 & Negatif & $1 \times 10^{2}$ & Memenuhi syarat \\
R2 & Negatif & $1 \times 10^{2}$ & Memenuhi syarat \\
R3 & Negatif & $1 \times 10^{2}$ & Memenuhi syarat \\
R4 & Negatif & $1 \times 10^{2}$ & Memenuhi syarat \\
R5 & Negatif & $1 \times 10^{2}$ & Memenuhi syarat \\
R6 & Negatif & $1 \times 10^{2}$ & Memenuhi syarat \\
R7 & Negatif & $1 \times 10^{2}$ & Memenuhi syarat \\
\hline
\end{tabular}

Berdasarkan dari hasil penelitian yang telah dilakukan pada babi panggang karo di rumah makan khas Batak Kecamatan Kuta Selatan, Kuta dan Denpasar Timur menunjukkan bahwa sebanyak 7 (100\%) babi panggang karo negatif terkontaminasi oleh Staphylococcus aureus dengan nilai $0 \mathrm{koloni} / \mathrm{gram}$ dan memenuhi syarat batas cemaran mikroba pada olahan daging dengan perlakuan panas berdasarkan SNI 7388:2009. Adapun batasan maksimum cemaran S.aureus dalam olahan daging dengan perlakuan panas adalah $1 \times 10^{2} \mathrm{koloni} / \mathrm{g}$. Berdasarkan hasil survei wawancara dan pengamatan yang dilakukan secara langsung, tidak adanya kontaminasi bakteri S.aureus pada babi panggang karo di rumah makan khas Batak di Kecamatan Kuta Selatan, Kuta dan Denpasar Timur karena menerapkan personal higiene yang baik. Penerapan personal higiene yang baik seperti memiliki kondisi kesehatan yang baik, menggunakan pakaian kerja yang bersih, tidak sedang batuk dan pilek, serta tidak memiliki luka pada kulit. Praktek personal higiene yang baik merupakan salah satu upaya pencegahan kontaminasi S.aureus pada makanan seperti menghindarkan pekerja yang sedang sakit dalam proses pengolahanan, tidak memiliki luka pada kulit, menjaga kuku tangan bersih dan pendek.

Dari hasil wawancara yang dilakukan sebanyak 100\% karyawan tidak diizinkan bekerja jika dalam keadaan sakit dengan tujuan agar tidak terjadi kontaminasi bakteri patogen antara pengolah dengan makanan yang akan dijual. Selain itu penggunaan capit saat pengambilan babi panggang karo merupakan cara yang tepat sehingga tidak terjadi kontak langsung tangan pekerja dengan babi panggang karo. Menurut Muzafri (2019), kandungan flavonoid pada ekstrak andaliman sangat efektif untuk menghambat pertumbuhan bakteri S.aureus, flavonoid yang bersifat polar sehingga lebih mudah menembus lapisan peptide glikan mikroba yang juga bersifat polar. S.aureus mengandung polisakarida yang merupakan polimer larut dalam air yang berfungsi sebagai ion positif untuk keluar masuk, terganggunya dinding sel menyebabkan lisis pada sel. Beberapa jenis rempah lainnya seperti bawang merah, bawang putih, cabai dan jahe juga memiliki aktivitas antimikroba yang cukup tinggi sehingga dapat menghambat pertumbuhan bakteri S.aureus (Jennie et al, 1992). 


\section{KESIMPULAN DAN SARAN}

\section{Kesimpulan}

Berdasarkan hasil penelitian yang telah dilakukan maka dapat disimpulkan beberapa hal sebagai berikut:

1. Terdeteksi sebanyak $57 \%$ babi panggang karo yang dijual di rumah makan khas Batak di Kecamatan Kuta Selatan, Kuta dan Denpasar Timur tidak memenuhi syarat batas cemaran E.coli pada produk olahan daging dan sebanyak $100 \%$ babi panggang karo yang dijual di rumah makan khas Batak di Kecamatan Kuta Selatan, Kuta dan Denpasar Timur sudah memenuhi syarat batas cemaran S.aureus pada produk olahan daging.

2. Babi panggang karo yang dijual di rumah makan khas Batak di Kecamatan Kuta Selatan, Kuta dan Denpasar Timur, belum memenuhi syarat untuk di konsumsi karena tingginya cemaran E.coli yang dapat berpengaruh terhadap kesehatan konsumenS.

\section{Saran}

Berdasarkan hasil penelitian disarankan untuk:

1. Sebaiknya daging babi yang sudah dicampur dengan bumbu rempah secepatnya dipanggang karena jika daging mengalami perubahan dari suhu ruang dan suhu dingin secara berulang dapat meningkatkan kontaminasi, sehingga mempercepat pertumbuhan bakteri.

2. Meningkatkan praktek sanitasi dan higiene di rumah makan khas Batak di Kecamatan Kuta Selatan, Kuta dan Denpasar Timur dengan menggunakan kelengkapan karyawan pada saat pengolahan untuk menghindari kontaminasi dengan mikroba patogen.

\section{DAFTAR PUSTAKA}

Anonimus. (2008). SNI 2897:2008. Metode Pengujian Cemaran Mikroba dalam Daging, Telur, dan Susu, serta hasil olahannya. Badan Standardisasi Nasional. Jakarta.

Anonimus. (2009). SNI 7388:2009. Batas Maksimum Cemaran Mikroba Pada Pangan. Badan Standarisasi Nasional, Jakarta.

Anonimus. (2019). Babi Panggang Karo. http://id.m.wikipedia.org/wiki/Babi_Panggan g_Karo. Diakses pada tanggal 10 mei 2019.

Endang, M., Mulyana, E.V.Indria. dan M. Avi. (2013). Inventarisasi Makanan Tradisional Jawa serta Alternatif Pengembangannya. Skripsi. Tidak dipublikasikan. Universitas Negeri Yogyakarta. Yogyakarta.

Fardiaz, S. (1992). Mikrobiologi Pengelolaan Pangan. Departemen Pendidikan dan Kebudayaan Direktorat Jendral Pendidikan Tinggi, Pusat Antar Universitas Pangan dan Gizi. Institut Pertanian Bogor. Bogor.

Faridz. R.H., dan M. Anshari. (2007). Analisis Jumlah Bakteri Dan Keberadaan Eschechia coli Pada Pengelolahan Ikan Teri Nasi PT. Kelola Mina Laut Unit Sumenep. Skripsi. Tidak Dipublikasikan. Universitas Trunojoyo. Madura.

Gomez, K.A., dan Gomez, A.A. (1995). Prosedur Statistik dan Penelitian. Pertanian. Edisi Kedua. Jakarta: 13 - 16. Universitas Indonesia. Jakarta.

Irianto, K. (2006). Mikrobiologi: Menguak Dunia Mikroorganisme Jilid 2. CV. Yrama Widya. Bandung.

Jenie. B.S.L., K. Undriyani dan R. Dewanti. (2010). Pengaruh Konsentrasi Jahe dan Waktu Kontak terhadap aktivitas beberapa mikroba penyebab kerusakan pangan. Bul Ilmu dan Teknologi Pangan I1 1(2).

Knechtges, P. (2015). Keamanan Pangan Teori dan Praktik. Jakarta: Penerbit Buku Kedokteran EGC. Jakarta.

Laluraa L.F.H., Lohoo. $\mathrm{H}$ dan Hanny. W.M. (2014). Identifikkasi Bakteri Escherichia coli pada Ikan Selar (Selaroides sp.) Bakar di Beberapa Resto di Kota Manado. Vol. 2, no. 1, hal. 10-13. 
Muzafir, A. (2019). Uji Aktivitas Antimikroba Ekstrak Andaliman (Zanthoxylum acanthopodium DC.) pada Staphylococcus aureus. Skripsi. Tidak Dipublikasikan. Fakultas Pertanian. Univeristas Pasir Pangarayan. Riau.

Nanuwasa. (2007). Tata Cara Laksana Higiene Hidangan Keracunan dan Jenis Bakteria. Http://www.Ihsmakassar.com. Diakses tanggal: 10 Oktober 2020.

Pratidina, P., Y.H. Darundiati dan H. L. Dangiran. (2017). Hubungan Higiene dan Sanitasi dengan Kontaminasi Escherichia coli pada Jajanan Pedagang Kaki Lima di Sekolah Dasar Kelurahan Pendrikan Lor, Semarang. Jurnal Kesehatan Masyarakat. Vol 5. No. 5.

Sandjaja. (2009). Kamus Gizi. Jakarta. PT. Kompas Media Nusantara. Jakarta.

Saparinto, C. dan Hidayat, D. (2006). Bahan Tambahan Pangan. Kanisius; 2006. Yogyakarta.
Soeparno. (2009). Ilmu dan Teknologi Daging Cetakan kelima. Gadjah Mada University Press. Yogyakarta.

Sugiyono. (2001). Metode Penilaian. Bandung: Alfabeta.

Supar. (2005). Keamanan Pangan Produk Peternakan Ditinjau Dari Aspek Prapanen: Permasalahan dan Solusi. Hlm 56-60. Prosiding Lokakarya Nasional Keamanan Pangan Produk Peternakan. Pusat Penelitian dan Pengembangan Peternakan. Bogor.

Supardi, I. dan Sukamto. (1999). Mikrobiologi Dalam Pengolahan dan Keamanan Pangan. Penerbit Alumni. Bandung.

Tamaroh. (2002). Praktek Pengolahan Pangan Yang Baik, Pelatihan Pengendalian Mutu dan Keamanan Pangan Bagi Pengajar, Kerjasama Pusat Study Pangan dan Gizi IPB dengan DikJen DIKTI. Departemen Pendidikan dan Kebudayaan. Bogor. 